\title{
Article \\ Exploring Supply Chain Collaboration for Green Innovations: Evidence from the High-Tech Industry in Poland
}

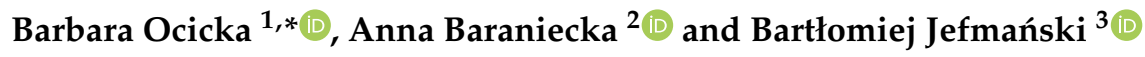 \\ 1 Risk Management Unit, Institute of Corporate Finance and Investment, SGH Warsaw School of Economics, \\ 02-554 Warsaw, Poland \\ 2 Department of Strategic Management and Logistics, Faculty of Management, \\ Wroclaw University of Economics and Business, 53-345 Wroclaw, Poland; anna.baraniecka@ue.wroc.pl \\ 3 Department of Econometrics and Computer Science, Wroclaw University of Economics and Business, \\ 53-345 Wroclaw, Poland; bartlomiej.jefmanski@ue.wroc.pl \\ * Correspondence: barbara.ocicka@sgh.waw.pl
}

Citation: Ocicka, B.; Baraniecka, A.; Jefmański, B. Exploring Supply Chain Collaboration for Green Innovations: Evidence from the High-Tech Industry in Poland. Energies 2022, 15, 1750.

https://doi.org/10.3390/en15051750

Academic Editors: Paula Bajdor and Audrius Banaitis

Received: 17 December 2021

Accepted: 23 February 2022

Published: 26 February 2022

Publisher's Note: MDPI stays neutral with regard to jurisdictional claims in published maps and institutional affiliations.

Copyright: (c) 2022 by the authors. Licensee MDPI, Basel, Switzerland. This article is an open access article distributed under the terms and conditions of the Creative Commons Attribution (CC BY) license (https:/ / creativecommons.org/licenses/by/ $4.0 /)$.

\begin{abstract}
The purpose of this article is to investigate whether the wide scope of supply chain collaboration including both customers and suppliers (Upstream-downstream External Collaboration) determines the greening of innovation more significantly than the scope limited only to suppliers (Upstream External Collaboration) or customers (Downstream External Collaboration). This goal was achieved as part of extensive research on the impact of relational capital on the innovativeness of high-tech companies in Poland. The results of the research were analysed using fuzzy conversion scales and descriptive statistics based on triangular fuzzy numbers. The application of the achievements of the fuzzy sets theory made it possible to test the hypotheses presented in the article with the use of fuzzy analysis of variance (fuzzy ANOVA). The findings confirm that the subjective scope of collaboration in the supply chain is important for greening innovation. Companies that cooperate with both suppliers and customers (Upstream-downstream External Collaboration) declared a greater tendency to green their innovations than those that cooperate with only one group of partners. The research findings contribute to the literature on the role of collaboration in the ecological responsibility and environmental performance of supply chain partners. The conclusions may have practical implications for the design and implementation of strategies in sustainable supply chain management. The study provides important lessons for SC managers facing the challenge of sustainable management during and after the COVID-19 outbreak.
\end{abstract}

Keywords: eco-innovation; green innovation; supply chain collaboration; sustainable supply chain management; sustainable development; high-tech; fuzzy measurement; fuzzy conversion scales

\section{Introduction}

In the era of intensified competitive struggle and the individualisation of customer needs or increased customer expectations, building a competitive advantage on one's own is basically impossible. Cooperation is essential, including cooperation in the supply chain. Supply chain entities create cross-organisational linkages because they have something to gain. They voluntarily agree to integrate human, information, financial, or technical resources in order to create a better business model [1]. Supply chain collaboration (SCC) is increasingly important to the success of modern organisations [2]. By engaging in cooperation in the supply chain, companies can increase the capacity of the supply chain, which in turn contributes to improving the efficiency of the company itself and ultimately guarantee a competitive advantage [3]. In particular, SCC makes it possible to achieve the complementary effect of supply chain competencies on building innovation capability [4]. Cooperation between supply chain links within the creation of innovation plays a central role as a source of value and competitive advantage. Innovation co-creation can foster innovation development through the joint efforts of the focal company and its supply chain 
partners, simultaneously bringing about a collaborative advantage and improving the economic, environmental, and social performance of all engaged parties, finally enhancing the sustainable competitiveness of engaged parties [2,5-7]. Organisations strive for excellence to balance the achievement of economic goals and the protection of the environment through both collaboration and innovation in SC [8]. Taking into account the fact that environmental supply chain collaboration covers various practices [9], this study is focused on eco-innovations. It addresses the call for more research on the link between collaboration and eco-innovations [10]. As Yang and Lin (2020) [11] highlighted, interrelationships between the development of green innovations and SCC are still under-explored; these two research fields are "hot streams of research in recent years". In this article, we address the research gap concerning the impact of the subjective scope of collaboration in the supply chain on the greening of innovation.

The purpose of our considerations is to determine whether the wide scope of collaboration including both customers and suppliers (Upstream-downstream External Collaboration) determines the greening of innovation more significantly than the scope limited only to suppliers (Upstream External Collaboration) or customers (Downstream External Collaboration).

This paper is structured as follows. Section 2 provides a theoretical background regarding the essence and types of supply chain collaboration, making an attempt to emphasise its importance to the development of green innovations. Subsequently, Section 3 presents materials and methods. Next, Section 4 is focused on the research results in order to investigate which scope of subjective SCC has the greatest impact on the degree of greening of innovation. The idea is also to understand the role of SCC in the greening of innovation. In Section 5 the authors discuss the findings and their implications. Finally, Section 6 highlights the main conclusions and future research directions.

\section{Theoretical Background}

\subsection{The Essence and Types of Cooperation in the Supply Chain}

Collaboration is an essential component of the supply chain management (SCM) paradigm and is embedded in every definition of this concept. How we understand collaboration depends on the interpretation of the terms: supply chain and supply chain management. The concept of the supply chain can be understood in three ways [12]:

- In terms of structural approach (as cooperating entities, such as mining, production, trade, and service companies, as well as their suppliers and customers between whom the flow of goods, information, and financial resources takes place;

- In terms of process approach (as a combination of processes between companies in the supply chain);

- In the subject-matter approach (as a bidirectional flow of goods and information from the place of extraction of raw materials to the final consumer).

In this article, the authors analyse the supply chain using a structural approach.

Among the approaches to the supply chain, the most readable and widespread is the one that indicates the relationship between entities on the economic path of the product. A simple picture of the supply chain understood in this way is presented in Figure 1. The supply chain itself is a natural form of exchange of goods, information, and cash; managing it consciously and purposefully is the source of many benefits.

The authors' research interest concerns the entire supply chain (including second or third-tier suppliers and customers). Unfortunately, the supply chain leaders most often indicate first-tier suppliers and customers as the area of direct cooperation. This situation also applies to the research carried out by the authors. 


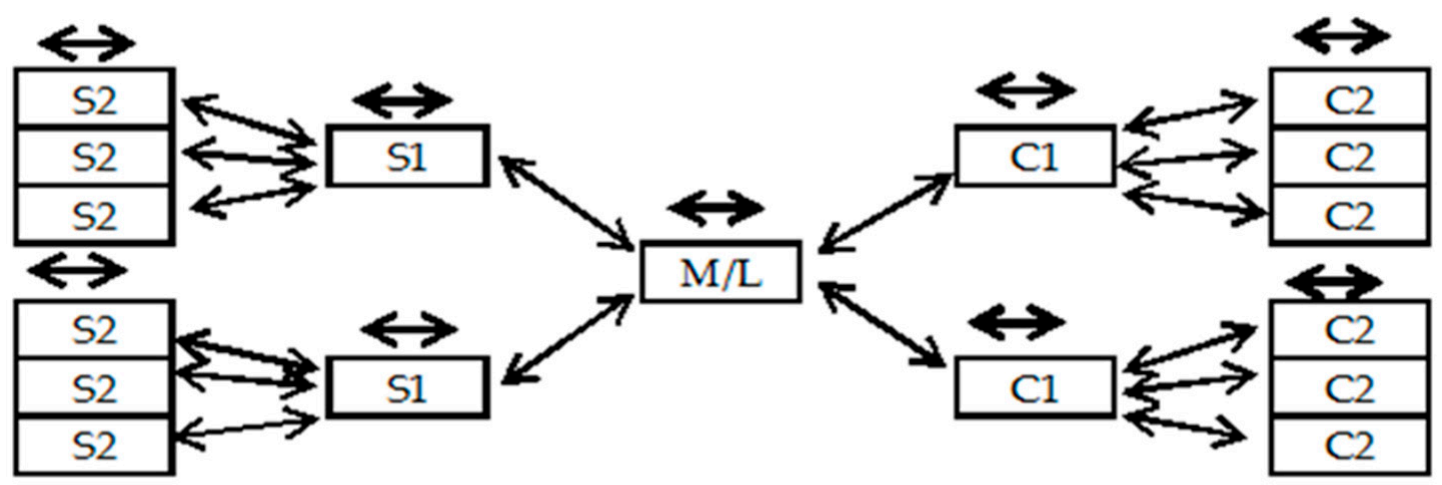

M/L-Manufacturer/Leader

S1-First-Tier Supplier

C1-First-Tier Customer

S2-Second-Tier Supplier

C2-Second-Tier Customer

$\longleftrightarrow$ Internal (intra-organizational) flows of products, information and cash

$\longleftrightarrow$ Extemal (inter-organizational) flows of products, information and cash

Figure 1. Supply chain visualisation.

The intensive development of the SCM concept on theoretical and practical grounds has led to many approaches and interpretations. Mentzer et al. classified the definitions of SCM into three categories: a set of management processes, a management philosophy, and the implementation of a management philosophy [13]. When defining SCM as a management philosophy, it is assumed that the supply chain is an extended enterprise. This affects how it is managed [14]. In the discussed approach, it is assumed that each company in the supply chain influences the final efficiency of the supply chain [15]. The implementation of the philosophy of the extended enterprise means taking specific actions, especially such as [13] (p. 8):

- Cooperation;

- The same strategic goal;

- Focusing on serving the final customer;

- Process integration;

- $\quad$ Sharing risks and rewards;

- $\quad$ Sharing information (information symmetry);

- Building and maintaining partnership relations.

The activities indicated in the process of supply chain management are also the principles that should accompany collaboration in the supply chain.

Supply Chain Cooperation (SCC) means companies undertake similar or complementary activities that are coordinated to obtain better mutual results [16]. Collaboration is not initiated just for a single transaction occurs at both strategic and operational management levels [15]. As Witkowski (2018) [12] (p. 4) pointed out, at the same time, each of the links in the supply chain has a certain autonomy in building its position, striving to achieve the set goal and sharing the benefits resulting from the synergistic aspects of cooperation.

Many definitions of supply chain collaboration highlight its various aspects and benefits. According to Mentzer et al. (2001) [13], supply chain collaboration is how companies involved in the supply chain react together to achieve common goals. The effectiveness of cooperation determines the sharing of knowledge, information, profits and risk. The key importance of sharing information, risk and benefits in collaboration in the supply chain is also emphasised by Goffin et al. (2006) [17], Hogarth-Scott (1999) [18] or Barratt and Oliveira (2001) [19]. Simatupang and Sridharan (2008) [20] described common goals as the key determinants of cooperation in the supply chain. The authors define 
"supply chain collaboration" as the joint work of two or more companies within the supply chain to meet the needs of end customers. The primary goals of the collaboration are the optimisation of profit for all chain partners and the creation of a competitive advantage. As important features defining collaboration in the supply chain, Carter et al. (2000) [21] indicated commitment and trust. These features change the quality, cost, and time efficiency of the relationship between partners. Horvath (2001) [22] recognised the advantages of collaboration and points to them as the driving force behind supply chain development.

In conclusion, it can be indicated that successful cooperation requires many actions, often contrary to the popular transactional approach (transaction-based contacts). To increase the effectiveness of collaboration in the supply chain and thus increase the benefits resulting from it, the following will be contributed: the free exchange of data, information, knowledge, and plans [23,24]; the implementation of a common goal and/or strategy [25]; joint decision making [20]; fair sharing of risk and benefits [26]; or building relationships based on trust and commitment, among others [27].

There are a variety of forms of supply chain collaboration, which, among others, Barratt (2004) [28] divided into two categories (see Figure 2):

- Vertical (external collaboration with suppliers and customers);

- Horizontal (collaboration with competitors, internally and with non-competitors, e.g., sharing manufacturing capacity) [29].

Vertical

Collaboration

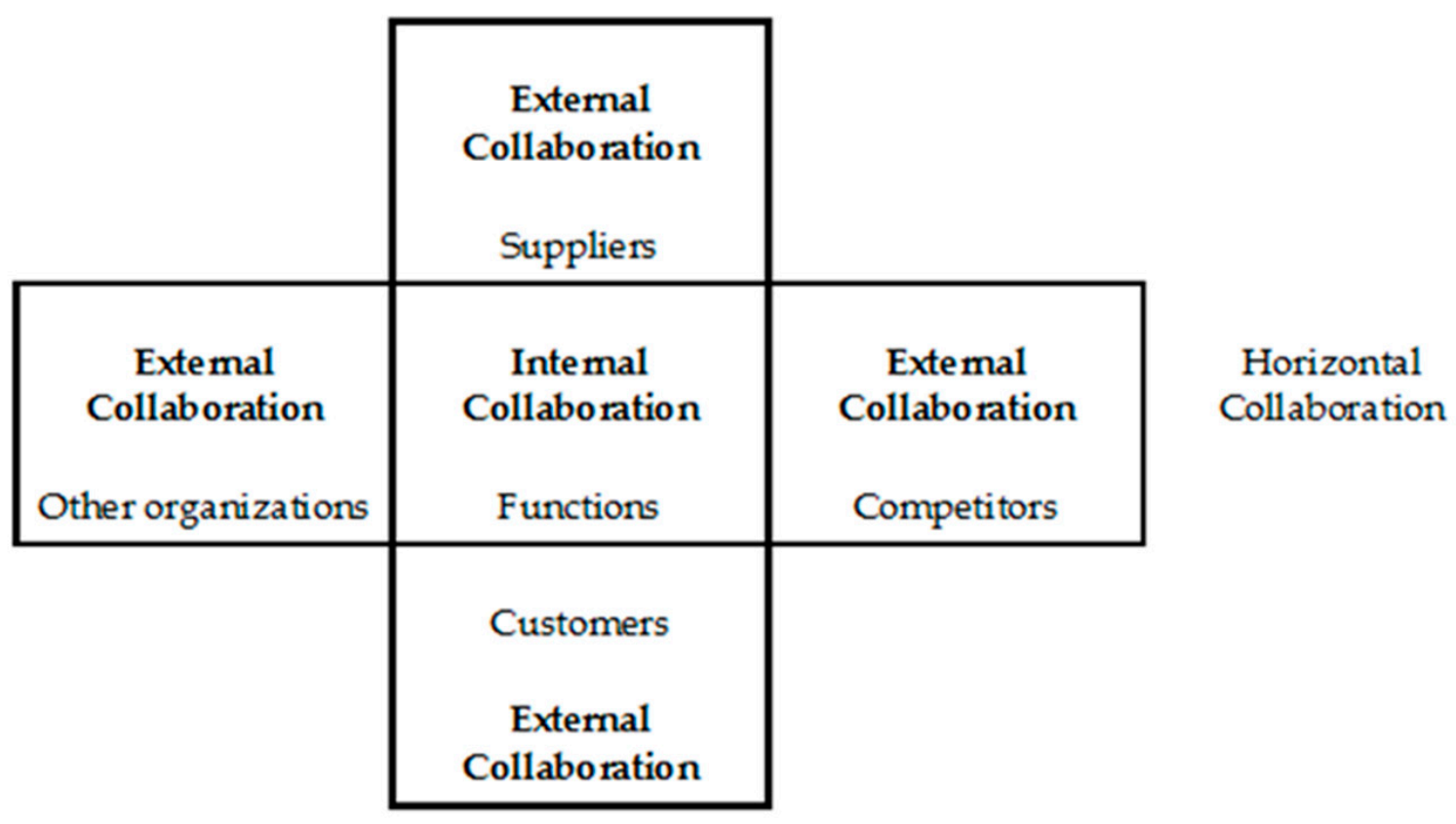

Figure 2. The scope of collaboration.

In a later part of the article, due to the adopted goal, external vertical cooperation is discussed (collaboration with suppliers and customers).

External vertical cooperation, due to its scope, can be further divided into cooperation at the top of the supply chain, i.e., with suppliers (Upstream External Collaboration); cooperation focusing on the lower part of the supply chain, i.e., with customers (Downstream External Collaboration); and simultaneous cooperation in the lower and upper supply chain, i.e., with both suppliers and customers (Upstream-downstream External Collaboration). See Figure 3.

The relationship between the above forms of collaboration (related to the scope of cooperation) and their effects are discussed later in this paper. 


\begin{tabular}{|c|c|c|c|}
\hline Suppliers & $\begin{array}{l}\text { Company/ } \\
\text { Leader }\end{array}$ & Customers & $\begin{array}{l}\text { Upstream External } \\
\text { Collaboration }\end{array}$ \\
\hline Suppliers & $\begin{array}{l}\text { Company/ } \\
\text { Leader }\end{array}$ & Customers & $\begin{array}{l}\text { Downstream External } \\
\text { Collaboration }\end{array}$ \\
\hline Suppliers & $\begin{array}{l}\text { Company/ } \\
\text { Leader }\end{array}$ & Customers & $\begin{array}{l}\text { Upstream-downstream External } \\
\text { Collaboration }\end{array}$ \\
\hline
\end{tabular}

Figure 3. Forms of external vertical collaboration as part of the realisation of selected processes, projects, or resource allocation.

\subsection{Supply Chain Collaboration for Eco-Innovations}

Many authors use the following terms interchangeably: eco-innovation, ecological innovation, environmental innovation, and green innovation [30-33]. Eco-innovations can be analysed considering the following [34]:

- Targets described as the focus areas of eco-innovation;

- Mechanisms perceived as the ways in which changes are made to the targets;

- Impacts referring to the effects of eco-innovations on the environment.

They cover a wide range of eco-innovation targets, including products, services, processes, ideas, solutions, and technologies, as well as business, management and marketing methods, organisational structures, or institutional arrangements [35-41]. The ways in which eco-innovations are developed can be systemised as follows: modification, redesign, alternatives, and creation [34]. The common goal of their development is to achieve diverse environmental effects (e.g., reduction of environmental risk, water, air pollution, $\mathrm{CO} 2$ emissions, or energy use) compared to previous solutions or available relevant alternatives. Eco-innovations provide value to the company and customers by significantly decreasing harmful environmental impacts [35] and simultaneously improving economic performance [36]. It is imperative to consider the value provided throughout the eco-innovation lifecycle, including benefits for the natural environment, in particular by minimising the consumption of natural resources per unit of manufactured product and hazardous substances during the manufacturing of the product, as well as both during and after its usage [38,39]. Green innovations result in significant progress towards the goal of sustainable development by reducing the impacts of production modes on the environment, enhancing resilience to environment pressures, or achieving a more efficient and responsible use of natural resources [40]. For example, energy eco-innovations lead to improvements in energy efficiency [42] and stimulate the sustainable development of enterprises [43].

Taking into account the plethora of types of eco-innovation, the collaborative development of product eco-innovations (also called green product innovations) is the subject of further analysis. This type of eco-innovation refers to products that have less environmental impact, consume less energy and fewer resources, have lower emissions and thus a smaller footprint, and incorporate more environmentally friendly materials than previous product generations [44]. Green product innovations deal with climate change more effectively [45]. Previous research studies have proven that both suppliers and customers contribute significantly to the development of product eco-innovations bringing benefits and adding value through new technologies, innovative materials, or knowledge of markets, products, and services [46-48]. However, there are no studies presenting the comparison of the impact of Upstream External Collaboration with suppliers, Downstream External Collaboration with customers, and Upstream-downstream External Collaboration with both suppliers and customers on the development of eco-innovation. 


\section{Materials and Methods}

Empirical research in the field of management sciences is frequently based on the results of measuring the opinions and attitudes of enterprise managers. In such cases, ordinal measurement scales are most often used as measurement tools, among which the popular Likert scale is included. The Likert scale is known for its psychometric properties; however, researchers are not always aware that the application of this scale determines the spectrum of statistical methods which can be used at the stage of analysing the findings. It should be emphasized that the Likert scale adopts equal distances between categories, which is rarely met due to the subjective nature of the respondents' opinions. The respondents' subjectivism in their perception of the categories of ordinal scales, including the Likert scale, rather leads to the assumption that the categories of scale are perceived differently. This, in turn, may result in errors in the estimates of basic descriptive statistics, including, among others, the arithmetic mean, which requires measurement on an interval or ratio scale. Therefore, the application of fuzzy conversion scales is becoming increasingly popular in empirical research. Taking a highly simplified approach, the use of these scales consists of converting measurement results on ordinal scales to the form of fuzzy numbers, most often being triangular fuzzy numbers. Following such conversion, various categories of ordinal measurement scales are represented by triangular fuzzy numbers.

The measurement of respondents' opinions applying fuzzy conversion scales which use triangular fuzzy numbers has also settled in the research addressing the area of supply chain management (see e.g., [49-57]). Among these scales, the most common ones are fivepoint scales [50-57]. Seven- and ten-point scales are used less frequently (see, e.g., [49,52]). These scales differ in categories (linguistic values); however, their conversion is very similar. Most of the categories on such scales are replaced by the symmetric triangular fuzzy numbers of equal spans. The extreme categories, replaced by asymmetric triangular fuzzy numbers, are the exception. These numbers differ from the other in terms of their span. The parameters of the triangular fuzzy numbers on the fuzzy conversion scales are determined based on different values. A popular approach is to determine the parameters of triangular fuzzy numbers based on values in the range $[0,1]$. There are also studies which use values from the following ranges [1,9] [56], [1, 10] [52], or [0, 100] [50]. In other areas where fuzzy conversion scales are applied, the parameter values of triangular fuzzy numbers in the range of $[1,5]$ are often used [58]. The source literature does not provide any recommendations regarding the parameter values of triangular fuzzy numbers used in fuzzy conversion scales. The scales with symmetric and equal-span fuzzy numbers assigned to the Likert scale categories dominate in the existing research.

Definition 1 [59]. If $X$ is a collection of objects denoted generically by $x$, then a fuzzy set $\widetilde{A}$ in $X$ is a set of ordered pairs:

$$
\widetilde{A}=\left\{\left(x, \mu_{\widetilde{A}}(x)\right) \mid x \in X\right\}
$$

where $\mu_{\widetilde{A}}$ is the membership function that maps $X$ to the membership space $M$, and $\mu_{\widetilde{A}}(x)$ is the grade of membership (also degree of compatibility or degree of truth) of $x$ in $\widetilde{A}$.

Definition 2 [60]. A fuzzy number is a fuzzy subset in the universe of discourse $X$ that is both convex and normal.

Definition 3 [60]. A triangular fuzzy number $A^{\prime}$ can be defined by a triplet $(a, b, c)$. The membership function $\mu_{A^{\prime}}(x)$ is defined as:

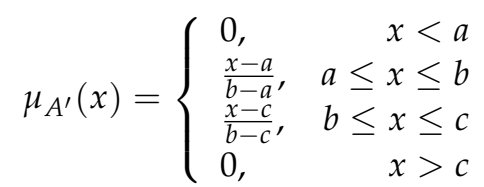


The graphic form of a triangular fuzzy number is shown in Figure 4.

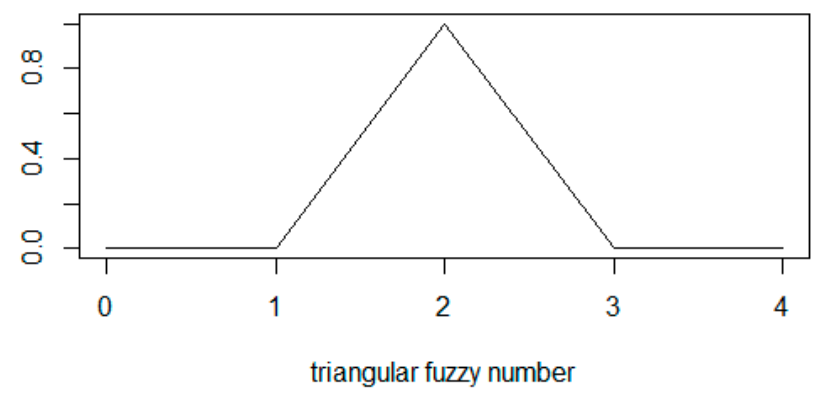

Figure 4. An example of a triangular fuzzy number.

Definition 4 . [58] The scale of fuzzy numbers is the class $F_{C}^{*}(R)$ of the nonempty, compact, convex, and normalized fuzzy sets of $R$, that is, the space of the mappings $\widetilde{U}: R \rightarrow[0,1]$ such that, for each $\alpha \in[0,1]$, the $\alpha$-level $\widetilde{U}_{\alpha}$ is a nonempty compact interval, where $\widetilde{U}_{\alpha}=\{x \in R: \widetilde{U}(x) \geq \alpha\}$ for $\alpha>0$ and $\widetilde{U}_{\alpha}=c l\{x \in R: \widetilde{U}(x)>0\}$.

A fuzzy conversion scale of verbal values/responses is often either explicitly or implicitly based on the Likert $k$-point scale, and it consists of converting each of the $k$ points into a fuzzy number. A conversion scale means a finite subset of $F_{C}^{*}(R)$ [58]. An example of a fuzzy conversion scale with five categories is shown in Figure 5.

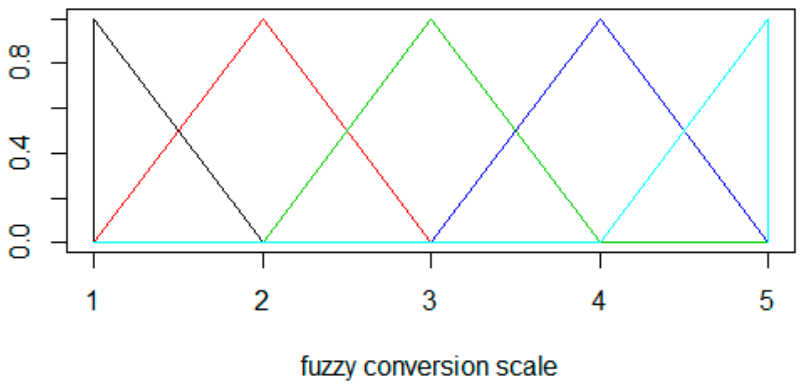

Figure 5. An example of a fuzzy conversion scale.

As can be noticed, the categories are represented by triangular fuzzy numbers. Therefore, the "high" category is represented by a triangular fuzzy number whose left domain range, middle value, and right domain range take the values $\mathrm{a}=0.2, \mathrm{~b}=0.4$, and $\mathrm{c}=0.6$, respectively.

If the researcher's goal is to examine the differences between the mean values of a feature, then the analysis of variance can be applied. If the feature was measured using fuzzy conversion scales and triangular fuzzy numbers, then the fuzzy analysis of variance is used. The analysis of variance for triangular fuzzy numbers was proposed in [61,62].

The following two hypotheses were examined in the fuzzy analysis of variance:

$$
\begin{gathered}
H_{0}: \widetilde{\mu}_{1}=\widetilde{\mu}_{2}=\ldots,=\widetilde{\mu}_{r} \\
H_{1}: \operatorname{notall} \widetilde{\mu}_{i}^{\prime} \mathrm{s}(i=1,2, \ldots, r) \text { are equal, }
\end{gathered}
$$

where $\tilde{\mu}_{i}$ is the average value of the characteristic expressed in the form of triangular fuzzy number for the $i$-th group.

The article uses fuzzy conversion scales and fuzzy analysis of variance to assess the differences in managers' opinions regarding the impact of greening innovation on the scope of cooperation in the supply chain. The research process discussed in the article carried out using fuzzy conversion scales and the analysis of variance are shown in Figure 6. 
Measurement of managers' opinions using the Likert scale.

Determining parameters of the fuzzy conversion scale.

Transformation of the results of managers' opinion measurement into the form of triangular fuzzy numbers.

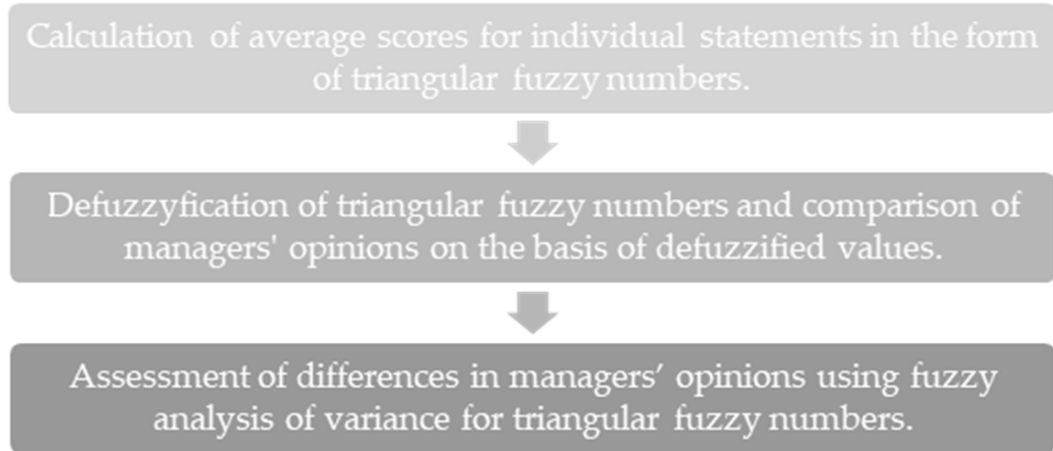

Figure 6. Total research flow chart.

\section{Results}

In order to achieve the research goal set out in the article, a questionnaire study was carried out under which the managers were asked to respond to five statements (s) regarding the creation of innovations, taking into account their impact on the environment:

$\mathrm{s}_{1}$ : Innovations in our company are developed taking into account their impact on the environment;

$\mathrm{s}_{2}$ : One of the reasons for implementing innovations is their positive influence on reducing the negative impact of our company on the environment;

$\mathrm{s}_{3}$ : Innovations are not implemented if their potential negative impact on the environment is predicted with great certainty;

$\mathrm{s}_{4}$ : Ecological approach to the development of innovations is an important criterion for the selection and rating of our partners;

$\mathrm{s}_{5}$ : The indicators for the implementation of innovations include indicators related to the environmental impact (e.g., the level of waste consumption, the level of carbon footprint, the level of water footprint, and others).

Collecting managers' opinions regarding the above statements was one of the goals of a more extensive study addressing "The impact of relational capital on the innovation of enterprises from high-tech sectors". The survey was conducted on a target sample of 120 high-tech enterprise managers operating in Poland between 15 September 2021 and 22 September 2021. The representatives of enterprises which implemented innovation projects within the framework of grants and/or cooperation with national agencies supporting the development of entrepreneurship and innovation in Poland, including, in particular, the Polish Agency for Enterprise Development PARP, were invited to participate in the study. The survey was carried out using the mixed-mode technique. The interviews based on a questionnaire were conducted using the CATI technique (indicated as the main technique) and the CAWI technique (when the respondent indicated this technique as more convenient for him/her). The Likert scale was used in measuring opinions using the following statements: "I strongly disagree", "I disagree", "I neither disagree nor agree", "I agree", and "I strongly agree". 
The measurement results were transformed into fuzzy conversion scales. One of the most frequently used approaches in the source literature was applied, in which the parameters of triangular fuzzy numbers are determined based on the values in the range of $[1,5][58]$. The parameters of the triangular fuzzy numbers are listed in Table 1.

Table 1. Parameters of the triangular fuzzy numbers for the fuzzy conversion scale.

\begin{tabular}{clll}
\hline \multirow{2}{*}{ Categories } & \multicolumn{3}{c}{ Triangular Fuzzy Numbers } \\
\cline { 2 - 4 } & $\mathbf{a}$ & $\mathbf{b}$ & $\mathbf{c}$ \\
\hline I strongly disagree & 1 & 1 & 2 \\
I disagree & 1 & 2 & 3 \\
I neither disagree nor agree & 2 & 3 & 4 \\
I agree & 3 & 4 & 5 \\
I strongly agree & 4 & 5 & 5 \\
\hline
\end{tabular}

The average ratings of five statements in the form of triangular fuzzy numbers divided into three groups are presented in Tables 2-4.

Table 2. Average ratings of the statements presented by the enterprise representatives in the form of triangular fuzzy numbers (a group of customers vs. a group of suppliers).

\begin{tabular}{ccccccc}
\hline \multirow{2}{*}{ Statements } & \multicolumn{3}{c}{ Customers } & \multicolumn{3}{c}{ Suppliers } \\
\cline { 2 - 7 } & $\mathbf{a}$ & $\mathbf{b}$ & $\mathbf{c}$ & $\mathbf{a}$ & $\mathbf{b}$ & $\mathbf{c}$ \\
\hline $\mathrm{s}_{1}$ & 3.204 & 4.184 & 4.612 & 3.357 & 4.357 & 4.714 \\
$\mathrm{~s}_{2}$ & 3.020 & 3.980 & 4.531 & 3.107 & 4.036 & 4.536 \\
$\mathrm{~s}_{3}$ & 2.980 & 3.938 & 4.500 & 3.148 & 4.111 & 4.593 \\
$\mathrm{~s}_{4}$ & 2.500 & 3.438 & 4.208 & 2.741 & 3.704 & 4.444 \\
$\mathrm{~s}_{5}$ & 2.830 & 3.766 & 4.362 & 3.074 & 4.037 & 4.519 \\
\hline
\end{tabular}

Table 3. Average ratings of the statements presented by the enterprise representatives in the form of triangular fuzzy numbers (a group of customers vs. a group of customers and suppliers jointly).

\begin{tabular}{ccccccc}
\hline \multirow{2}{*}{ Statements } & \multicolumn{3}{c}{ Customers } & \multicolumn{3}{c}{ Customers + Suppliers } \\
\cline { 2 - 7 } & $\mathbf{a}$ & $\mathbf{b}$ & $\mathbf{c}$ & $\mathbf{a}$ & $\mathbf{b}$ & $\mathbf{c}$ \\
\hline $\mathrm{s}_{1}$ & 3.204 & 4.184 & 4.612 & 3.550 & 4.550 & 4.800 \\
$\mathrm{~s}_{2}$ & 3.020 & 3.980 & 4.531 & 3.138 & 4.069 & 4.552 \\
$\mathrm{~s}_{3}$ & 2.980 & 3.938 & 4.500 & 3.316 & 4.316 & 4.737 \\
$\mathrm{~s}_{4}$ & 2.500 & 3.438 & 4.208 & 2.700 & 3.700 & 4.500 \\
$\mathrm{~s}_{5}$ & 2.830 & 3.766 & 4.362 & 3.263 & 4.263 & 4.684 \\
\hline
\end{tabular}

Table 4. Average ratings of the statements presented by the enterprise representatives in the form of triangular fuzzy numbers (a group of suppliers vs. a group of customers and suppliers jointly).

\begin{tabular}{ccccccc}
\hline \multirow{2}{*}{ Statements } & \multicolumn{3}{c}{ Suppliers } & \multicolumn{3}{c}{ Customers + Suppliers } \\
\cline { 2 - 7 } & $\mathbf{a}$ & $\mathbf{b}$ & $\mathbf{c}$ & $\mathbf{a}$ & $\mathbf{b}$ & $\mathbf{c}$ \\
\hline $\mathrm{s}_{1}$ & 3.357 & 4.357 & 4.714 & 3.550 & 4.550 & 4.800 \\
$\mathrm{~s}_{2}$ & 3.107 & 4.036 & 4.536 & 3.138 & 4.069 & 4.552 \\
$\mathrm{~s}_{3}$ & 3.148 & 4.111 & 4.593 & 3.316 & 4.316 & 4.737 \\
$\mathrm{~s}_{4}$ & 2.741 & 3.704 & 4.444 & 2.700 & 3.700 & 4.500 \\
$\mathrm{~s}_{5}$ & 3.074 & 4.037 & 4.519 & 3.263 & 4.263 & 4.684 \\
\hline
\end{tabular}

The comparison of the average ratings in the form of triangular fuzzy numbers is not possible without their defuzzification. For this purpose, two popular methods of defuzzification triangular fuzzy numbers were used: median and centre of gravity (CoG). 
The mean ratings after defuzzification for the individual compared groups are listed in Tables 5-7.

Table 5. Average ratings of the statements presented by the enterprise representatives after defuzzification the triangular fuzzy numbers (a group of customers vs. a group of suppliers).

\begin{tabular}{ccccc}
\hline \multirow{2}{*}{ Statements } & \multicolumn{2}{c}{ Customers } & \multicolumn{2}{c}{ Suppliers } \\
\cline { 2 - 5 } & CoG & Median & CoG & Median \\
\hline $\mathrm{s}_{1}$ & 4.000 & 4.046 & 4.143 & 4.196 \\
$\mathrm{~s}_{2}$ & 3.844 & 3.878 & 3.893 & 3.929 \\
$\mathrm{~s}_{3}$ & 3.806 & 3.839 & 3.951 & 3.991 \\
$\mathrm{~s}_{4}$ & 3.382 & 3.396 & 3.630 & 3.648 \\
$\mathrm{~s}_{5}$ & 3.653 & 3.681 & 3.877 & 3.917 \\
\hline
\end{tabular}

Table 6. Average ratings of the statements presented by the enterprise representatives after defuzzification the triangular fuzzy numbers (a group of customers vs. a group of customers and suppliers jointly).

\begin{tabular}{ccccc}
\hline \multirow{2}{*}{ Statements } & \multicolumn{2}{c}{ Customers } & \multicolumn{2}{c}{ Customers + Suppliers } \\
\cline { 2 - 5 } & CoG & Median & CoG & Median \\
\hline $\mathrm{s}_{1}$ & 4.000 & 4.046 & 4.300 & 4.363 \\
$\mathrm{~s}_{2}$ & 3.844 & 3.878 & 3.920 & 3.957 \\
$\mathrm{~s}_{3}$ & 3.806 & 3.839 & 4.123 & 4.171 \\
$\mathrm{~s}_{4}$ & 3.382 & 3.396 & 3.633 & 3.650 \\
$\mathrm{~s}_{5}$ & 3.653 & 3.681 & 4.070 & 4.118 \\
\hline
\end{tabular}

Table 7. Average ratings of the statements presented by the enterprise representatives after defuzzification the triangular fuzzy numbers (a group of suppliers vs. a group of customers and suppliers jointly).

\begin{tabular}{ccccc}
\hline \multirow{2}{*}{ Statements } & \multicolumn{2}{c}{ Suppliers } & \multicolumn{2}{c}{ Customers + Suppliers } \\
\cline { 2 - 5 } & CoG & Median & CoG & Median \\
\hline $\mathrm{s}_{1}$ & 4.143 & 4.196 & 4.300 & 4.363 \\
$\mathrm{~s}_{2}$ & 3.893 & 3.929 & 3.920 & 3.957 \\
$\mathrm{~s}_{3}$ & 3.951 & 3.991 & 4.123 & 4.171 \\
$\mathrm{~s}_{4}$ & 3.630 & 3.648 & 3.633 & 3.650 \\
$\mathrm{~s}_{5}$ & 3.877 & 3.917 & 4.070 & 4.118 \\
\hline
\end{tabular}

Descriptive statistics for the defuzzified measurement results broken down into three groups are presented in Tables 8-10.

Table 8. Descriptive statistics for a group of customers.

\begin{tabular}{ccccc}
\hline \multirow{2}{*}{ Statements } & \multicolumn{2}{c}{ Mean } & Std. Deviation & $\begin{array}{c}\text { Coefficient of } \\
\text { Variation (\%) }\end{array}$ \\
\cline { 2 - 3 } & Statistic & Std. Error & & 23.250 \\
$\mathrm{~s}_{1}$ & 4.000 & 0.133 & 0.930 & 25.416 \\
$\mathrm{~s}_{2}$ & 3.844 & 0.140 & 0.977 & 27.036 \\
$\mathrm{~s}_{3}$ & 3.806 & 0.148 & 1.029 & 30.781 \\
$\mathrm{~s}_{4}$ & 3.382 & 0.151 & 1.041 & 29.948 \\
$\mathrm{~s}_{5}$ & 3.653 & 0.160 & 1.094 & \\
\hline
\end{tabular}


Table 9. Descriptive statistics for a group of suppliers.

\begin{tabular}{ccccc}
\hline \multirow{2}{*}{ Statements } & \multicolumn{2}{c}{ Mean } & Std. Deviation & $\begin{array}{c}\text { Coefficient of } \\
\text { Variation (\%) }\end{array}$ \\
\cline { 2 - 3 } & Statistic & Std. Error & & 19.382 \\
$\mathrm{~s}_{1}$ & 4.143 & 0.152 & 0.803 & 26.689 \\
$\mathrm{~s}_{2}$ & 3.893 & 0.196 & 1.039 & 24.956 \\
$\mathrm{~s}_{3}$ & 3.951 & 0.190 & 0.986 & 26.749 \\
$\mathrm{~s}_{4}$ & 3.630 & 0.187 & 0.971 & 27.212 \\
$\mathrm{~s}_{5}$ & 3.877 & 0.203 & 1.055 & \\
\hline
\end{tabular}

Table 10. Descriptive statistics for a group of customers and suppliers jointly.

\begin{tabular}{|c|c|c|c|c|}
\hline \multirow{2}{*}{ Statements } & \multicolumn{2}{|c|}{ Mean } & \multirow{2}{*}{ Std. Deviation } & \multirow{2}{*}{$\begin{array}{l}\text { Coefficient of } \\
\text { Variation }(\%)\end{array}$} \\
\hline & Statistic & Std. Error & & \\
\hline $\mathrm{s}_{1}$ & 4.300 & 0.153 & 0.683 & 15.884 \\
\hline $\mathrm{s}_{2}$ & 3.920 & 0.205 & 0.917 & 23.393 \\
\hline $\mathrm{s}_{3}$ & 4.123 & 0.184 & 0.803 & 19.476 \\
\hline $\mathrm{s}_{4}$ & 3.633 & 0.186 & 0.830 & 22.846 \\
\hline $\mathrm{S}_{5}$ & 4.070 & 0.199 & 0.892 & 21.916 \\
\hline
\end{tabular}

To determine whether the observed differences in the opinions of managers are statistically significant, the fuzzy ANOVA was used. For each of the statements, the null hypothesis that the average opinions of managers are not significantly different in the analysed groups was verified. The level of significance was set at 0.05 . The results of the hypothesis verification for each statement are presented in Table 11.

Table 11. Fuzzy ANOVA results.

\begin{tabular}{ccccc}
\hline Groups & Statements & $\tilde{\boldsymbol{F}}$-Statistic & $\boldsymbol{p}$-Value & Test Results \\
\hline & $\mathrm{s}_{1}$ & 0.527 & 0.470 & Accept $\mathrm{H}_{0}$ \\
customers vs. & $\mathrm{s}_{2}$ & 0.024 & 0.877 & Accept $\mathrm{H}_{0}$ \\
suppliers & $\mathrm{s}_{3}$ & 0.391 & 0.534 & Accept $\mathrm{H}_{0}$ \\
& $\mathrm{~s}_{4}$ & 0.857 & 0.358 & Accept $\mathrm{H}_{0}$ \\
& $\mathrm{~s}_{5}$ & 0.859 & 0.357 & Accept $\mathrm{H}_{0}$ \\
customers vs. & $\mathrm{s}_{1}$ & 1.918 & 0.171 & Accept $\mathrm{H}_{0}$ \\
customers and & $\mathrm{s}_{2}$ & 0.520 & 0.474 & Accept $\mathrm{H}_{0}$ \\
suppliers jointly & $\mathrm{s}_{3}$ & 1.629 & 0.206 & Accept $\mathrm{H}_{0}$ \\
& $\mathrm{~s}_{4}$ & 0.671 & 0.415 & Accept $\mathrm{H}_{0}$ \\
& $\mathrm{~s}_{5}$ & 2.422 & 0.125 & Accept $\mathrm{H}_{0}$ \\
suppliers vs. & $\mathrm{s}_{1}$ & 0.553 & 0.461 & Accept $\mathrm{H}_{0}$ \\
customers and & $\mathrm{s}_{2}$ & 0.144 & 0.706 & Accept $\mathrm{H}_{0}$ \\
suppliers jointly & $\mathrm{s}_{3}$ & 0.430 & 0.515 & Accept $\mathrm{H}_{0}$ \\
& $\mathrm{~s}_{4}$ & -0.020 & 1.000 & Accept $\mathrm{H}_{0}$ \\
& $\mathrm{~s}_{5}$ & 0.450 & 0.506 & Accept $\mathrm{H}_{0}$ \\
\hline
\end{tabular}

The null hypothesis was not rejected in any of the cases. This means that despite the existence of differences in the opinions of managers, we cannot consider them statistically significant.

Although the fuzzy analysis of variance indicates that group response differences are not statistically significant, it is worth looking at the results when considering subtle but nonetheless present differences. Thus, the comparative analysis showed differences in the statements of the three studied groups against the greening of innovation. In all statements, the lowest level of responses were obtained by the group "Customers", where the surveyed entities cooperate in the supply chain in terms of innovation only with customers, the group "Suppliers" (collaboration only with suppliers) obtained a higher level of response, and the highest level of responses was received by the group, which combined collaboration in 
terms of innovation with both suppliers and customers (see Figure 7). In our study, this means that the subjective scope of collaboration affects the scale of innovation greening. This impact is even more visible by observing the differences between the individual positions of groups with a single co-operator and those cooperating simultaneously with both co-operators (see Figure 8).

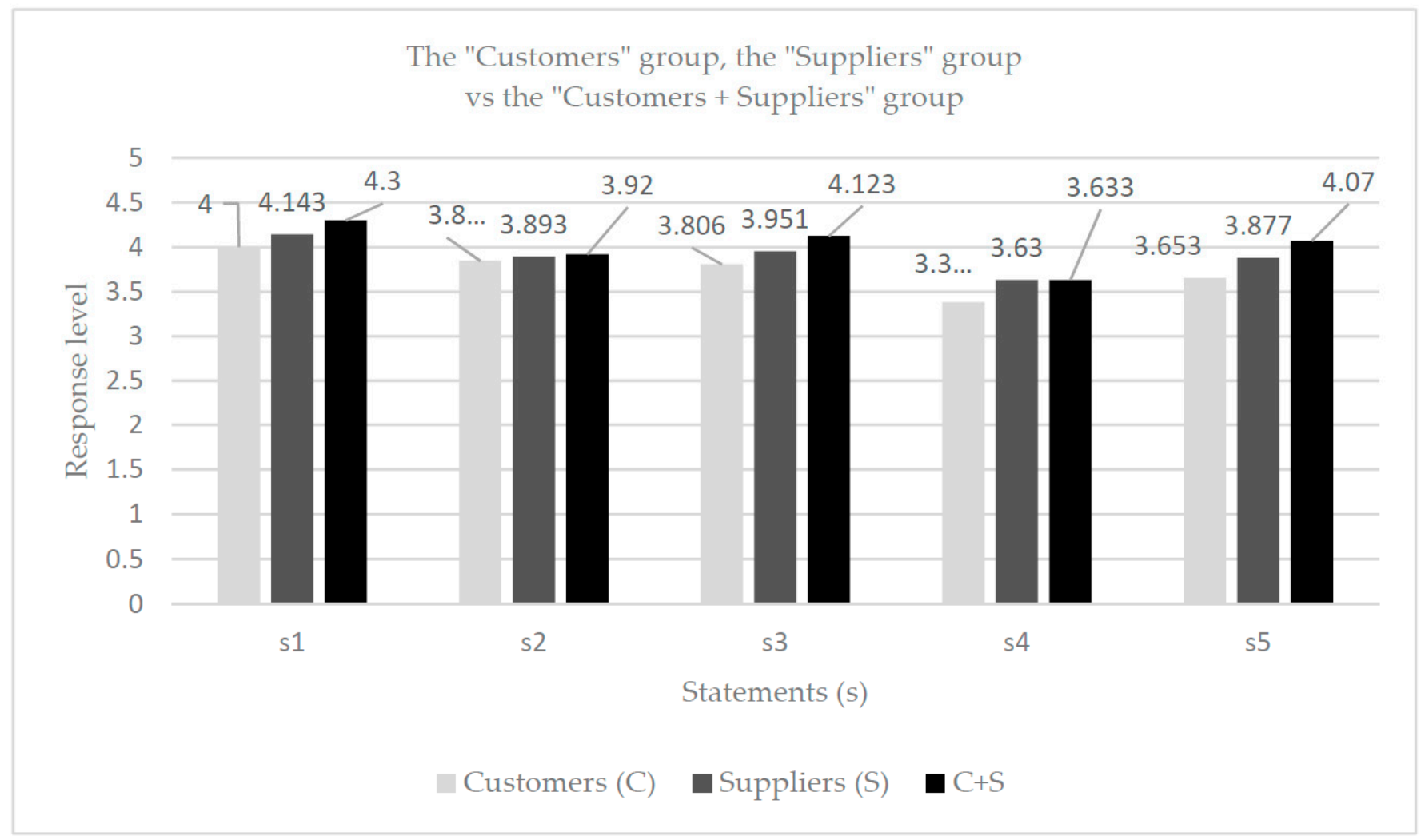

Figure 7. Comparison of statements (s) presented by representatives of enterprises in the Groups: Customers (C), Suppliers (S), and Customers and Suppliers $(C+S)$.

Considering the results in the context of the presented positions, it can be noticed that the largest ones occur in the case of theorem $5\left(s_{5}\right)$ : The indicators for the implementation of innovations include indicators related to the environmental impact (e.g., the level of waste consumption, the level of carbon footprint, the level of water footprint and others). This may mean that taking more advanced actions in the greening of innovation such as monitoring and evaluation systems requires a greater scope of cooperation, reaching the bottom and the top of the supply chain.

The slightest difference in the reactions of the studied groups concerns theorem $2\left(\mathrm{~s}_{2}\right)$ : One of the reasons for implementing innovations is their positive influence on reducing the negative impact of our company on the environment. This position is related to the "green" image of companies, which may lead to universal declarations in this regard. Implementing such a position does not require a wide range of collaboration.

Based on the research results, the level of innovation greening in relation to the scope of subjective collaboration in the supply chain can be light, standard, and strong (see Figure 9). 


\section{The difference between the level of response in the case of cooperation} with one group of cooperators (C or S) and cooperation with both

$$
\text { groups }(\mathrm{C}+\mathrm{S})
$$

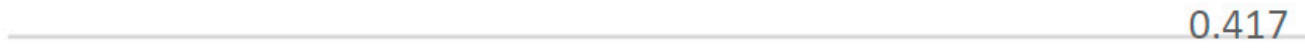

0.4

0.35

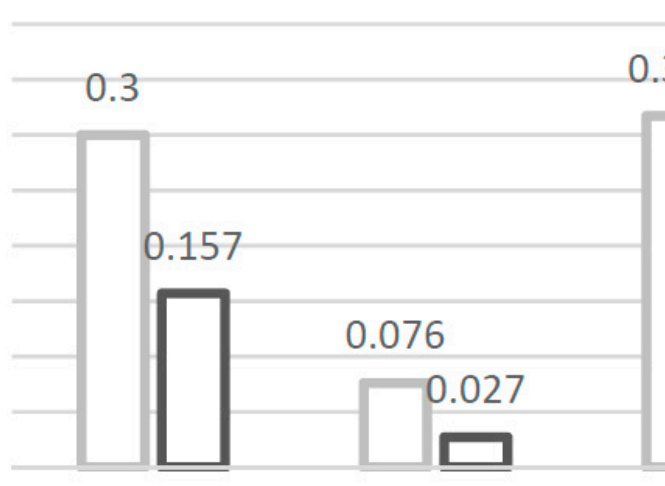

0.317

0.3

0.25

0.2

0.15

0.1

0.05

0

s1

s2

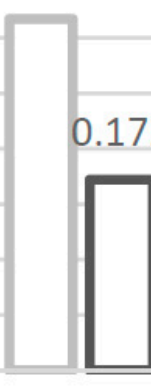

s3

Statements (s)

The difference between the "Customers" group and the "Customers + Suppliers" group

The difference between the "Suppliers" group and the "Customers + Suppliers" group

Figure 8. The level of differences in the statements between the Groups: Customers vs. Customers and Suppliers and Suppliers vs. Customers and Suppliers.

\begin{tabular}{c|c|c|} 
Group & $\begin{array}{c}\text { Forms of external vertical } \\
\text { collaboration }\end{array}$ & $\begin{array}{c}\text { The degree of greening } \\
\text { of innovation }\end{array}$ \\
\hline Group "Customers" & Upstream External & $\begin{array}{c}\text { Light greening of } \\
\text { innovation }\end{array}$ \\
& Collaboration & Greening of \\
Group "Suppliers" & Downstream External & Collaboration \\
Group "Customers + & Upstream-downstream & Strong greening of \\
Suppliers" & External Collaboration & innovation \\
\hline
\end{tabular}

Figure 9. The level of the greening of innovation depends on the subjective scope of cooperation in the supply chain.

\section{Discussion}

Authors worldwide have analysed and discussed many benefits resulting from collaboration in the supply chain. Min et al. (2005) [63] reviewed the literature in this area and identified the following as the most important benefits: increased supply chain capabilities (better demand planning, inventory visibility, new knowledge) and improved supply chain efficiency and effectiveness. Singha et al. (2018) [64] distinguished the detailed benefits of cooperation in the supply chain. These are reduced supply chain costs, increased revenues, improved product availability and responsiveness, improved quality, increased sharing of information, accurate forecasting, enhanced competitiveness, and reduced lost sales. Another significant beneficial effect of collaboration in the supply chain 
is an increase in innovation [65], including eco-innovation [66]. Considering SCC in generating eco-innovations, researchers underlined the predominance of the open innovation paradigm based on interactions with customers, suppliers, and other stakeholders [43]. An in-depth empirical study developed by Acebo et al. (2021) [67] confirmed that collaboration with external partners increases companies' likelihood of eco-innovation. Triguero et al. (2018) [68] argued that collaboration leads to the development of the fastest and easiest ways to develop eco-innovations. Based on a systematic literature review, Araújo and Franco (2021) [69] confirmed that an appropriate choice of partners is the key factor in developing interorganisational collaboration towards eco-innovation. Our analysis confirmed the significance of SCC for eco-innovation development and revealed that its subjective scope affects the degree of the greening of innovations. Furthermore, we enrich the literature through the comparison of the impact of Upstream External Collaboration with suppliers, Downstream External Collaboration with customers, and Upstream-downstream External Collaboration with both suppliers and customers on the development of eco-innovation.

Next, it is worth considering the results of our research in the context of strategic management and building a sustainable competitive advantage of enterprises and supply chains. Our research study contributes to the ongoing debate on the question of how enterprises can incorporate environmental aspects into strategic management [70]. A corporate environmental strategy usually aims to increase the efficiency of the use of natural resources, while minimising its impact on the natural environment [71]. Its implementation covers different business areas across the organisation (business units and functions) and across the supply chain (structures, processes, relations). The results of our research revealed that SCC can be one of the pillars influencing the greening of innovations. Collaboration with supply chain partners in the scope of eco-innovations can be part of a proactive and interactive environmental strategy [72,73], and its importance depends on the maturity of the ecological strategy [74]. We would like to underline the fact that environmental SCC has gained strategic importance [75] and has become critical in the face of a significant increase in the probability and severity of external environmental risks and environmental crises [76] in today's volatile, uncertain, complex, and ambiguous (VUCA) global business landscape [77]. The results of the study conducted during the COVID-19 pandemic show that SCC is one of the crucial factors in the implementation of corporate environmental strategies in business nowadays.

In light of the literature review, SCC is very important to the development of green issues for supply chain sustainability. Deng et al. (2018) [78] pointed out that green SC collaborative innovations are becoming increasingly important in organisations for improving SC performance and dealing with the emerging challenge of protecting the environment. An et al. (2014) [79] argued that collaborative innovation is valuable in order for organisations to achieve a competitive advantage in environmental sustainability. Furthermore, Yenipazarli (2017) [80] took into consideration the positive impact of cooperation on the effectiveness of eco-innovation processes in the supply chain, examining and comparing situations when the entity does not cooperate with co-operators and when it invites suppliers to cooperate using two types of agreements, i.e., a cost-sharing agreement or a revenue-sharing agreement [80]. Another very interesting topic related to our research is SC cooperation on innovations while greening them. Gerstlberger et al. (2014) [81] paid special attention to innovations in the field of increasing energy efficiency. In the quoted article, the authors stated that reconciling product innovation and energy efficiency is a complex and intertwined process-focusing on one can have indirect detrimental effects on the other. Therefore, they postulated that in the practice of innovation management, the specificity and interactions of various types of innovations and their environmental implications should be considered more carefully. In the opinion of the authors, it is also necessary to formulate new, more sustainable management practices combining energy efficiency and product innovations. Increasing energy efficiency is treated as a significant and positive impact of the company on the environment, and one of the factors that improves the results of this action is collaboration with suppliers and customers in the 
supply chain. The scope of SCC refers to the planning and development of activities and projects requiring the involvement of an organisation, whether with its suppliers or with its customers, to jointly develop environmental solutions [82]. Our study revealed that companies that cooperate with both suppliers and customers (Upstream-downstream External Collaboration), declared a greater tendency to green their innovations than those that cooperate with only one group of partners.

We also identified that an earlier stage of cooperation in the supply chain (with suppliers) results in a higher degree of greening of innovation than cooperation at a later stage in the supply chain (with customers). Although innovations can be co-created in cooperation up and down the supply chain, the results of empirical studies developed by other authors show that suppliers are the most important group among supply chain links cooperating with manufacturers in the development of innovation. The literature specifies that between $40 \%$ and $60 \%$ of the possibilities of creating innovations in SC come from suppliers [83]. It was found that $83 \%$ of the companies surveyed globally by the Centre for Advanced Procurement Strategy have so far developed or plan to develop innovation development programs in cooperation with suppliers [84]. Experts from the Chartered Institute of Procurement and Supply also emphasise that building supplier partnerships is an important element of SC strategy as a potential source of innovation [85]. It is particularly strongly emphasised that the network of suppliers with the potential for innovation development is a valuable, scarce, and unimitated resource not replaceable by substitutes [86]. According to [87], the key expectation of production companies towards suppliers is focused on reducing the risk of noncompliance and limiting the negative environmental impact on processes and products. It has been proven that supplier collaboration in green and ethical supply management leads to higher focal company innovation performance [88]. The ability to manage the capital of relationships with suppliers determines its effective use for the diffusion of innovations.

In the course of our considerations, we indicated that collaboration on greening innovation in the upstream and downstream supply chain varies, mainly due to differences in bargaining power or the type of product and information flow (pull or push). Hence, undertaking cooperation may be associated with different conditions, generate different costs, and bring different results. The importance of collaboration in the upstream and downstream parts of the supply chain is discussed, among other authors, by Hofman et al. (2020) [66], emphasising that the effects of cooperation with suppliers and customers differ depending on the reasons for its initiation, which include community, market, and regulatory pressure. Moreover, the identified difference in the development of green innovations, depending on who the examined entity cooperates with, may originate in enterprise resource theory and be related to bargaining power. Resource dependence means that the company is embedded in a relationship network. Resource dependence theory views firms as embedded in a web of exchange relationships within an uncertain environment and dependent on other entities for survival [89]. Belonging to the supply chain, including long-term cooperation agreements, reduces the risk of losing access to resources but does not eliminate the differences in the bargaining power of the chain links [90]. The simplest manifestation of bargaining power is the pressure to reduce prices. This, however, only benefits one side. A much fairer manifestation of the use of bargaining power, being beneficial to both parties, is the fact that the stronger partner initiates activities related to reducing costs or increasing innovation [91]. Suppliers are most often subject to this power in the supply chain. Despite the fact that they have unique resources (e.g., raw materials, knowledge, infrastructure), their client's decisions influence how effectively they will use them. In addition, as proven by Crook and Combs (2007) [91], the involvement of suppliers in customer-initiated projects may increase the costs of switching suppliers, thereby strengthening their bargaining power and obtaining benefits from cooperation in the supply chain. The recipients in the supply chain usually have a high level of bargaining power and do not succumb to the influence of co-operators so easily, even if this influence would be beneficial to them. Such dependence may explain why the companies surveyed 
more often develop eco-innovative projects with suppliers. In addition, in many supply chains, especially high-tech ones, the suppliers are business partners, and the recipients may also be individual customers. This, too, could have determined the results of the research.

The results of our research can be used in the scientific discussion and practice of enterprises in the supply chain on research and development, including the onboarding process of co-operators, especially suppliers. Onboarding is mainly associated with employees, but it can also be applied in the area of supplier development [92] or building customer relationships [93]. Onboarding, or organisational socialisation, is a process that helps newcomers become integrated members of their organisation. Onboarding refers to the process that helps new employees learn the knowledge, skills, and behaviours they need to succeed in their new organisations [94]. Companies looking to green their innovations can learn about their environmental statements during the recruitment phase and/or develop them in collaboration through onboarding.

\section{Conclusions and Future Research}

The green revolution covers all areas of business activity, and the process of designing and implementing innovations is no different. Green innovations (eco-innovations) support sustainable development as an important manifestation of green issues for sustainability and the active participation of business in environmental protection and energy economics. As with any innovative activity, the success of green innovations is determined by a number of factors. In this paper, we analysed the relationship between the subjective scope of supply chain collaboration and the greening of innovations. The major takeovers of the analysis are summarised as follows.

First of all, supply chain collaboration is gaining strategic importance in terms of greening innovation as an integral part of the environmental and innovation strategies of contemporary high-tech enterprises. High-tech companies participating in research take environmental impact into account in their innovation development. Moreover, one of the reasons for implementing innovations is their positive influence on reducing the negative impact on the environment. An important conclusion which shows the importance of ecology in the innovative activities of high-tech companies is the respondents' declaration that they would be willing to withdraw a given innovation if it had a negative impact on the environment. This conclusion is reinforced by the further result, according to which it seems that the indicators for the implementation of innovations include those related to environmental impact (e.g., the level of waste consumption, the level of carbon footprint, the level of water footprint, and others).

Secondly, the results of our research confirm that the subjective scope of cooperation affects the scale of greening innovation. We have contributed to the existing literature by indicating the difference in the degree of greening innovation depending on the subjective scope of SCC. Companies that cooperate with both suppliers and customers (Upstreamdownstream External Collaboration) declared a greater tendency to green their innovations than those that cooperate with only one group of partners-suppliers or customers (Upstream External Collaboration and Downstream External Collaboration).

Another important conclusion is that an ecological approach to the development of innovations is an important criterion for the selection and rating of business partners. The development of eco-innovations can be an important purpose of collaboration in relations up and down the supply chain. As a result, the inclusion of eco-innovation co-creation in supply chain strategy is desirable. It is especially important to achieve synergy effects in both supplier and customers relationships management. We believe that the greening of innovations can be increased by extending cooperation to other supply chain partners. This means that SCC stimulates the development of green innovations and should be included in the strategic goals of sustainable supply chain management in the near future. Furthermore, relationships management has become a key competence of supply chain managers aiming to explore green innovations for supply chain sustainability. 
Finally, the definitions that can be drawn from the set of results given so far are important. The research results outlined the need for the definition of greening of innovation through the prism of reducing negative impact and taking the indicators into account in this regard (e.g., waste intensity, water and carbon footprint, energy usage and efficiency) across the entire innovation lifecycle. Additionally, the research findings provide a contribution to the definition of the coupled type of green innovation from the supply chain perspective, which involves two (or more) supply chain partners that purposively manage their collaboration for the joint development of green (eco) innovation. As a result, the incorporation of green issues for supply chain sustainability is more effective and efficient.

Our study gives rise to several avenues for future research on the impact of the scope of subjective cooperation on the development of eco-innovations. Future research directions should include the measurement of relational capital in the supply chain and its impact on making innovation processes and innovations greener. It will be important to develop multi-perspective research by extending the approach to multilateral supply chain relationships. Future research should also address the limitations of our study by broadening the analysis to include other industries so as to better understand the chances for the collaborative greening of innovations in sectors with different technological opportunities. It is worth considering the extension of the research scope on collaboration with other stakeholders, including competitors. The development of collaborative innovation with competitors could be an interesting research study, taking into account many legislations. The methodological aspects of using fuzzy measurement in the studies on supply chain management also require further research. The literature does not offer, among others, indications regarding the choice of the fuzzy conversion scale form. Therefore, an attractive direction for future research may be the application of an approach based on fuzzy scales (e.g., a fuzzy rating scale), in which the respondent decides, without any restraints, about the form of the fuzzy number which "best" describes his/her answer. Comparing the measurement results using fuzzy scales and fuzzy conversion scales may allow researchers to work out the form of a fuzzy conversion scale which corresponds even more strongly to the preferences of respondents.

Author Contributions: Conceptualization, B.O., A.B. and B.J.; methodology, B.O., A.B. and B.J.; validation, B.O., A.B. and B.J.; formal analysis, B.O., A.B. and B.J.; investigation, B.O., A.B. and B.J.; resources, B.O., A.B. and B.J.; data curation, B.O., A.B. and B.J.; writing-original draft preparation, B.O., A.B. and B.J.; writing-review and editing, B.O., A.B. and B.J.; visualization, B.O., A.B. and B.J.; supervision, B.O., A.B. and B.J.; administration, B.O., A.B. and B.J. All authors have read and agreed to the published version of the manuscript.

Funding: This research was funded by Wroclaw University of Economics and Business, grant number RG/WKR/21 "The impact of relational capital on the high-tech companies' innovativeness". The APC was funded by SGH Warsaw School of Economics, KNOP11/KPK/0242/21 and grant number RG/WKR/21 "The impact of relational capital on the high-tech companies' innovativeness".

Data Availability Statement: Not applicable.

Conflicts of Interest: The authors declare no conflict of interest.

\section{References}

1. Bowersox, D.J.; Closs, D.J.; Stank, T.P. How to master cross-enterprise collaboration. Supply Chain Manag. Rev. 2003, 7, 22.

2. Cao, M.; Zhang, Q. Supply chain collaboration impact on collaborative advantage and firm performance. J. Oper. Manag. 2011, 29, 163-180. [CrossRef]

3. Hardy, C.; Phillips, N.; Lawrence, T.B. Resources, knowledge and influence: The organizational effects of interorganizational collaboration. J. Manag. Stud. 2003, 40, 321-347. [CrossRef]

4. Liao, Y.; Li, Y. Complementarity effect of supply chain competencies on innovation capability. Bus. Process. Manag. J. 2019, 25, 1251-1272. [CrossRef]

5. Solaimani, S.; Van der Veen, J. Open Supply Chain Innovation: An Extended View on Supply Chain Collaboration. Available online: https:/ /www.researchgate.net/publication/353930677_Open_supply_chain_innovation_an_extended_view_on_supply_ chain_collaboration (accessed on 12 November 2021). 
6. Soosay, C.A.; Hyland, P. A decade of supply chain collaboration and directions for future research. Supply Chain Manag. Int. J. 2015, 20, 613-630. [CrossRef]

7. Zimmermann, R.; Ferreira, L.M.D.; Moreira, A.C. The influence of supply chain on the innovation process: A systematic literature review. Supply Chain Manag. Int. J. 2016, 21, 290-304. [CrossRef]

8. Lin, Y.-H.; Tseng, M.-L. Assessing the competitive priorities within sustainable supply chain management under uncertainty. J. Clean. Prod. 2016, 112, 2133-2144. [CrossRef]

9. Zhu, Q.; Sarkis, J. Relationships between operational practices and performance among early adopters of green supply chain management practices in Chinese manufacturing enterprises. J. Oper. Manag. 2004, 22, 265-289. [CrossRef]

10. Hong, J.; Zheng, R.; Deng, H.; Zhou, Y. Green supply chain collaborative innovation, absorptive capacity and innovation performance: Evidence from China. J. Clean. Prod. 2019, 241, 118377. [CrossRef]

11. Yang, Z.; Lin, Y. The effects of supply chain collaboration on green innovation performance: An interpretive structural modelling analysis. Sustain. Prod. Consum. 2020, 23, 1-10. [CrossRef]

12. Witkowski, J. Supply Chain Management in the Conditions of Globalization. In Japanese Supply Chain in Europe. Management and Development; Witkowski, J., Baraniecka, A., Eds.; PWE: Warszawa, Poland, 2018; p. 12.

13. Mentzer, J.T.; James, S.; Soonhong, M.; Nancy, W.; Carlo, D.; Zach, G. Defining Supply Chain Management. J. Bus. Logist. 2001, 22, 5-8. [CrossRef]

14. Ellram, L.M.; Cooper, M.C. Supply Chain Management, Partnerships, and the Shipper-Third-Party Relationship. Int. J. Logist. Manag. 1990, 1, 1-10. [CrossRef]

15. Cooper, M.C.; Lambert, D.M.; Pagh, J.D. Supply Chain Management: More Than a New Name for Logistics. Int. J. Logist. Manag. 1997, 1, 1-14. [CrossRef]

16. Anderson, J.C.; Narus, J.A. A Model of Distributor Firm and Manufacturer Firm Working Partnerships. J. Mark. 1990, 54, 42. [CrossRef]

17. Goffin, K.; Lemke, F.; Szwejczewski, M. An exploratory study of 'close' supplier- manufacturer relationships. J. Oper. Manag. 2006, 24, 189-209. [CrossRef]

18. Hogarth-Scott, S. Retailer-supplier partnerships: Hostages to fortune or the way forward for the millennium? Br. Food J. 1999, 101, 668-682. [CrossRef]

19. Barratt, M.; Oliveira, A. Supply chain collaboration: Exploring the early initiatives-part one. Supply Chain Pract. 2001, 3, 34-47.

20. Simatupang, T.M.; Sridharan, R. Design for supply chain collaboration. Bus. Process Manag. J. 2008, 14, 401-418. [CrossRef]

21. Carter, P.L.; Carter, J.R.; Monczka, R.M.; Slaight, T.H.; Swan, A.J. The future of purchasing and supply: A ten-year forecast. J. Supply Chain Manag. 2000, 36, 14-26. [CrossRef]

22. Horvath, L. Collaboration: The key to value creation in supply chain management. Supply Chain Manag. Int. J. 2001, 6, 205-207. [CrossRef]

23. Quinn, F.J. Cooperation and collaboration: The keys to supply chain success. Logist. Manag. Distrib. 1999, 38, 35.

24. Walker, B.; Bovet, D.; Martha, J. Unlocking the Supply Chain to Build Competitive Advantage. Int. J. Logist. Manag. 2000, 11, 1-8. [CrossRef]

25. Angerhofer, B.; Angelides, M. A model and a performance measurement system for collaborative supply chains. Decis. Support Syst. 2006, 42, 283-301. [CrossRef]

26. Witkowski, J. Supply Chain Management. Concepts, Procedures, Experiences; PWE: Warszawa, Poland, $2010 ;$ p. 40.

27. Kwon, I.W.G.; Suh, T. Factors affecting the level of trust and commitment in supply chain relationships. J. Supply Chain Manag. 2004, 40, 4-14. [CrossRef]

28. Barratt, M. Understanding the meaning of collaboration in the supply chain. Supply Chain Manag. Int. J. 2004, 9, 30-42. [CrossRef]

29. Simatupang, T.M.; Sridharan, R. The collaborative supply chain. Int. J. Logist. Manag. 2002, 13, 15-30. [CrossRef]

30. Dias Angelo, F.; Jabbour, C.J.C.; Vasconcellos Galina, S. Environmental innovation: In search of a meaning. World J. Entrep. Manag. Sustain. Dev. 2012, 8, 113-121. [CrossRef]

31. Charter, M.; Clark, T. Sustainable Innovation Key Conclusions Sustainable Innovation Conferences 2003-2006 Organised by the Centre for Sustainable Design. 2007. Available online: https://www.researchgate.net/publication/228383595_ Sustainable_Innovation_Key_conclusions_from_Sustainable_Innovation_Conferences_2003-2006_organised_by_The_Centre_ for_Sustainable_Design (accessed on 15 November 2021).

32. Hojnik, J.; Ruzzier, M. What drives eco-innovation? A review of an emerging literature. Environ. Innov. Soc. Transit. 2016, 19, 31-41. [CrossRef]

33. Karakaya, E.; Hidalgo, A.; Nurr, C. Diffusion of eco-innovations: A review. Renew. Sustain. Energy Rev. 2014, 33, 392-399. [CrossRef]

34. OECD. Eco-Innovation in Industry: Enabling Green Growth; OECD: Paris, France, 2010.

35. Fussler, C.; James, P. Eco-Innovation: A Breakthrough Discipline for Innovation and Sustainability; Pitman Publishing: London, UK, 1996; p. 303.

36. Rennings, K. Redefining innovation-Eco-innovation research and the contribution from ecological economics. Ecol. Econ. 2000, 32, 319-322. [CrossRef]

37. Kemp, R.; Pearson, P. Final Report MEI Project about Measuring Eco Innovation. 2017. Available online: https://www.oecd.org/ env/consumption-innovation/43960830.pdf (accessed on 30 October 2021). 
38. Woźniak, L.; Strojny, M.; Wojnicka, E. Jak Budować Przewagę Konkurencyjna Dzięki Ekoinnowacyjności? Polska Agencja Przedsiębiorczości: Rzeszów, Poland, 2010.

39. Bartoszczuk, P. Mechanizmy Powstawania Efektów Ekoinnowacji w Przedsiębiorstwach w Polsce; Oficyna Wydawnicza SGH: Warsaw, Poland, 2018.

40. European Commission. Eco-Innovation the Key to Europe's Future Competitiveness; European Commission: Brussels, Belgium, 2013.

41. Pichlak, M.; Szromek, A.R. Eco-Innovation, Sustainability and Business Model Innovation by Open Innovation Dynamics. J. Open Innov. Technol. Mark. Complex. 2021, 7, 149. [CrossRef]

42. Walton, S.; Zhang, A.; O'Kane, C. Energy eco-innovations for sustainable development: Exploring organizational strategic capabilities through an energy cultures framework. Bus. Strategy Environ. 2020, 29, 812-826. [CrossRef]

43. Carrillo-Hermosilla, J.; del González, P.R.; Könnöla, T. (Eds.) What is Eco-Innovation? In Eco-Innovation. When Sustainability and Competitiveness Shake Hands; Palgrave Macmillan: London, UK, 2009; pp. 6-27.

44. Melander, L. Customer and Supplier Collaboration in Green Product Innovation: Internal and External Capabilities. Bus. Strategy Environ. 2018, 27, 677-693. [CrossRef]

45. Porter, M.E.; Van der Linde, C. Toward a new conception of the environment-competitiveness relationship. J. Econ. Perspect. 1995, 9, 97-118. [CrossRef]

46. Foster, C.; Green, K. Greening the innovation process. Bus. Strategy Environ. 2000, 9, 287-303. [CrossRef]

47. Geffen, C.A.; Rothenberg, S. Suppliers and environmental innovation: The automotive paint process. Int. J. Oper. Prod. Manag. 2000, 20, 166-186. [CrossRef]

48. Dai, J.; Cantor, D.E.; Montabon, F.L. How environmental management competitive pressure affects a focal firm's environmental innovation activities: A green supply chain perspective. J. Bus. Logist. 2015, 36, 242-259. [CrossRef]

49. Bottani, E.; Rizzi, A.A. Fuzzy TOPSIS methodology to support outsourcing of logistics services. Supply Chain Manag. 2006, 11, 294-308. [CrossRef]

50. Kahraman, C.; Yasin Ateş, N.; Çevik, S.; Gülbay, M.; Ayça Erdoğan, S. Hierarchical fuzzy TOPSIS model for selection among logistics information technologies. J. Enterp. Inf. Manag. 2007, 20, 143-168. [CrossRef]

51. Zouggari, A.; Benyoucef, L. Simulation based fuzzy TOPSIS approach for group multi-criteria supplier selection problem. Eng. Appl. Artif. Intell. 2012, 25, 507-519. [CrossRef]

52. Rohmah, D.; Dania, W.; Dewi, I. Risk Measurement of Supply Chain Organic Rice Product Using Fuzzy Failure Mode Effect Analysis in MUTOS Seloliman Trawas Mojokerto. Agric. Agric. Sci. Procedia 2015, 3, 108-113. [CrossRef]

53. Kabra, G.; Ramesh, A. Analyzing drivers and barriers of coordination in humanitarian supply chain management under fuzzy environment. Benchmarking Int. J. 2015, 22, 559-587. [CrossRef]

54. Sinrat, S.; Atthirawong, W. Integrated Factor Analysis and Fuzzy Analytic Network Process (FANP) Model for Supplier Selection Based on Supply Chain Risk Factors. Res. J. Bus. Manag. 2015, 9, 106-123. [CrossRef]

55. Orji, I.J.; Wei, S. An innovative integration of fuzzy-logic and systems dynamics in sustainable supplier selection: A case on manufacturing industry. Comput. Ind. Eng. 2015, 88, 1-12. [CrossRef]

56. Kozarević, S.; Puška, A. Use of fuzzy logic for measuring practices and performances of supply chain. Oper. Res. Perspect. 2018, 5 , 150-160. [CrossRef]

57. Kaviani, M.A.; Tavana, M.; Kowsari, F.; Rezapour, R. Supply chain resilience: A benchmarking model for vulnerability and capability assessment in the automotive industry. Benchmarking Int. J. 2020, 27, 1929-1949. [CrossRef]

58. De Sáa, S.R.; Gil, M.A.; Garcia, M.T.L.; Lubiano, M.A. Fuzzy Rating vs Fuzzy Conversion Scales: An Empirical Comparison through the MSE. In Synergies of Soft Computing and Statistics AISC; Kruse, R., Ed.; Springer: Berlin/Heidelberg, Germany, 2013; Volume 190, pp. 143-153.

59. Zimmerman, H.J. Fuzzy Sets, Decision Making, and Expert Systems; Kluwer Academic Publishers: Boston, MA, USA, 1987 ; p. 11.

60. Chen, C.-T. Extensions of the TOPSIS for group decision-making under fuzzy environment. Fuzzy Sets Syst. 2000, 114, 1-9. [CrossRef]

61. Parchami, A.; Nourbakhsh, M.; Mashinchi, M. Analysis of variance in uncertain environments. Complex Intell. Syst. 2017, 3 189-196. [CrossRef]

62. Parchami, A. One-Way Analysis of Variance Based on Triangular Fuzzy Numbers. Retrieved August 2019. Available online: https:/ / cran.rproject.org/web/packages/ANOVA.TFNs/ANOVA.TFNs.pdf (accessed on 12 November 2021).

63. Min, S.; Roath, A.S.; Daugherty, P.J.; Genchev, S.E.; Chen, H.; Arndt, A.D. Supply Chain Collaboration: What's Happening? Int. J. Logist. Manag. 2005, 16, 239-240. [CrossRef]

64. Singha, H.; Garga, R.K.; Sachdeva, A. Supply chain collaboration: A state-of-the-art literature review. Uncertain Supply Chain Manag. 2018, 6, 149-180. [CrossRef]

65. Yunus, E.N. Leveraging supply chain collaboration in pursuing radical innovation. Int. J. Innov. Sci. 2018, 10, 350-370. [CrossRef]

66. Hofman, P.S.; Blome, C.; Schleper, M.C.; Subramanian, N. Supply Chain Collaboration and Eco-Innovations: An Institutional Perspective from China. Bus. Strategy Environ. 2020, 29, 2734-2754. [CrossRef]

67. Acebo, E.; Miguel-Dávila, J.A.; Nieto, M. External stakeholder engagement: Complementary and substitutive effects on firms eco-innovation. Bus. Strategy Environ. 2021, 30, 2671-2687. [CrossRef]

68. Triguero, A.; Fernández, S.; Sáez-Martinez, F.J. Inbound open innovative strategies and eco-innovation in the Spanish food and beverage industry. Sustain. Prod. Consum. 2018, 15, 49-64. [CrossRef] 
69. Araújo, R.; Franco, M. The use of collaboration networks in search of eco-innovation: A systematic literature review. J. Clean. Prod. 2021, 314, 127975. [CrossRef]

70. Sharma, S.; Vredenburg, H. Proactive corporate environmental strategy and the development of competitively valuable organizational capabilities. Strateg. Manag. J. 1998, 19, 729-753. [CrossRef]

71. Terence Tsai, S.H.; Child, J. Strategic Response of Multinational Corporations to Environmental Demands. J. Gen. Manag. 1997, 23, $1-22$.

72. Misiak, M.; Serwach, T. Ekologiczne Strategie Marketingowe Przedsiębiorstw Jako Wyraz Społecznej Odpowiedzialności Biznesu In Biznes We Współczesnej Gospodarce; Buczkowski, B., Kuna-Marszałek, A., Eds.; Wydawnictwo Uniwersytetu Łódzkiego: Łódź, Poland, 2016; pp. 115-135.

73. Żak, K. Proekologiczne Modele Biznesu Przedsiębiorstwa. Studia Ekonomiczne. Zesz. Nauk. Uniw. Ekon. Katowicach 2017, 322, 256-266.

74. Marzantowicz, Ł.; Ocicka, B.; Pluta-Zaremba, A. Ekologiczne Podejście do Tworzenia Łańcucha Wartości; Oficyna Wydawnicza SGH: Warszawa, Poland, 2021.

75. Chen, L.; Zhao, X.; Tang, O.; Price, L.; Zhang, S.; Zhu, W. Supply chain collaboration for sustainability: A literature review and future research agenda. Int. J. Prod. Econ. 2017, 194, 73-87. [CrossRef]

76. Word Economic Forum. The Global Risks Report 2021. Available online: https://www3.weforum.org/docs/WEF_The_Global_ Risks_Report_2021.pdf (accessed on 15 November 2021).

77. Bennett, N.; Lemoine, G.J. What VUCA really means for you. Harv. Bus. Rev. 2014, 92, 27.

78. Deng, H.; Karunasena, K.; Xu, W. Evaluating the performance of e-government in developing countries. Internet Res. 2018, 28, 169-190. [CrossRef]

79. An, X.; Deng, H.; Chao, L.; Bai, W. Knowledge management in supporting collaborative innovation community capacity building J. Knowl. Manag. 2014, 18, 574-590. [CrossRef]

80. Yenipazarli, A. To collaborate or not to collaborate: Prompting upstream eco-efficient innovation in a supply chain. Eur. J. Oper. Res. 2017, 260, 571-587. [CrossRef]

81. Gerstlberger, W.; Knudsen, M.P.; Stampe, I. Sustainable Development Strategies for Product Innovation and Energy. Bus. Strategy Environ. 2014, 23, 131-144. [CrossRef]

82. Vachon, S. Green supply chain practices and the selection of environmental technologies. Int. J. Prod. Res. 2007, 45, 4357-4379. [CrossRef]

83. Ferreiro, T.; Zappone-Fabre, E.; Cordón, C. The Organizational Design Shift. In The Value Chain Shift. Seven Challenges Facing Top Executives; Cordón, C., Ferreiro, T., Eds.; IMD Global Value Chain Center: Lausanne, Switzerland, 2014.

84. Jennings, R.J. Managing Supplier Innovation. CAPS Research 2015. Available online: https://www.capsresearch.org/ membership/library-summary/ (accessed on 14 January 2019).

85. The Chartered Institute of Procurement and Supply. Available online: http://www.cips.org/en/supply-management/opinion/ 2017 / october/three-ways-to-build-a-strong-supply-chain/ (accessed on 19 October 2020).

86. Yan, T.; Yang, S.; Dooley, K. A theory of supplier network-based innovation value. J. Purch. Supply Manag. 2017, 23, 153-162. [CrossRef]

87. Urbaniak, M.; Tundys, B.; Ankiel, M. Expectations of Production Companies Operating in Poland towards Suppliers with Regards to Implementation of the Sustainability Concept. Sustainability 2021, 13, 8683. [CrossRef]

88. Kähkönen, A.-K.; Lintukangas, K.; Ritala, P.; Hallikas, J. Supplier collaboration practices: Implications for focal firm innovation performance. Eur. Bus. Rev. 2017, 29, 402-418. [CrossRef]

89. Pfeffer, J.; Salancik, G. The External Control of Organizations: A Resource Dependence Perspective; Harper and Row: New York, NY, USA, 1978

90. Campbell, A. Cooperation in international value chains: Comparing an exporter's supplier versus customer relationships. J. Bus. Ind. Mark. 1998, 13, 22-39. [CrossRef]

91. Crook, T.R.; Combs, J.G. Sources and consequences of bargaining power in supply chains. J. Oper. Manag. 2007, 25, 546-555. [CrossRef]

92. Banerjee, A.; Lücker, F.; Ries, J.M. An empirical analysis of suppliers' trade-off behavior in adopting digital supply chain financing solutions. Int. J. Oper. Prod. Manag. 2021, 41, 313-335. [CrossRef]

93. Penttinen, E.; Rinta-Kahila, T. Onboarding customer companies to electronic invoicing platform-Developing a marketing and a partnering strategy for Tieto, an e-invoicing service provider. J. Inf. Technol. Teach. Cases 2017, 7, 43-50. [CrossRef]

94. Bauer, T.N.; Erdogan, B. Organizational Socialization: The Effective Onboarding of New Employees. In APA Handbook of Industrial and Organizational Psychology; Volume 3: Maintaining, Expanding, and Contracting the Organization; Zedeck, S., Ed.; American Psychological Association: Washington, DC, USA, 2011; pp. 51-64. 